\title{
Dystrophic calcifications and subcutaneous atrophy - rare complications of subcutaneous fat necrosis of the newborn
}

\section{Zwapnienia i zaniki tkanki tłuszczowej - rzadkie powikłanie obumierania podskórnej tkanki tłuszczowej noworodków}

Martyna Sławińska', Aleksandra Wilkowska', Agata Polkowska², Wojciech Biernat ${ }^{3}$, Iwona Domżalska-Popadiuk², Roman J. Nowicki', Michał Sobjanek'

\author{
'Department of Dermatology, Venereology and Allergology, Medical University of Gdańsk, Poland \\ 2Department of Neonatology, Medical University of Gdańsk, Poland \\ 3Department of Pathomorphology, Medical University of Gdańsk, Poland \\ 'Katedra i Klinika Dermatologii, Wenerologii i Alergologii, Gdański Uniwersytet Medyczny, Polska \\ 2Klinika Neonatologii, Gdański Uniwersytet Medyczny, Polska \\ ${ }^{3}$ Katedra i Zakład Patomorfologii, Gdański Uniwersytet Medyczny, Polska
}

\section{CORRESPONDING AUTHOR/ ADRES DO KORESPONDENCJI: \\ lek. Martyna Sławińska \\ Klinika Dermatologii, \\ Wenerologii i Alergologii \\ Gdański Uniwersytet Medyczny \\ ul. Kliniczna 1 A \\ 80-402 Gdańsk, Polska \\ tel.: +48583492581 \\ e-mail: mslawinska@gumed.edu.pl}

\begin{abstract}
Introduction. Subcutaneous fat necrosis of the newborn is a rare form of panniculitis observed predominantly in neonates within the first weeks of life. In most cases subcutaneous lesions resolve spontaneously without complications. Occasionally, however, dystrophic calcifications and subcutaneous atrophy are observed.

Objective. Presenting a case of a child with subcutaneous fat necrosis of the newborn and the clinical spectrum of the disease.

Case report. We present a male neonate affected by subcutaneous fat necrosis of the newborn complicated by dystrophic calcifications and subcutaneous atrophy.

Conclusions. From the clinical point of view, the most important factor to consider is the possible coexistence of subcutaneous fat necrosis of the newborn with a range of metabolic complications. The incidence of local complications (including dystrophic calcifications and subcutaneous atrophy) is rare. Patient follow-up is essential to determine future aesthetic and functional effects of the disease, and management of possible complications.
\end{abstract}

\section{STRESZCZENIE}

Wprowadzenie. Obumieranie podskórnej tkanki tłuszczowej noworodków jest rzadkim zapaleniem tkanki podskórnej, występującym najczęściej w pierwszych tygodniach życia. W większości przypadków zmiany w obrębie tkanki podskórnej ustępują samoistnie, nie pozostawiając śladu. Rzadko obserwowanym powikłaniem są podskórne zwapnienia dystroficzne oraz zaniki podskórnej tkanki tłuszczowej.

Cel pracy. Przedstawienie przypadku dziecka z obumieraniem podskórnej tkanki tłuszczowej noworodków oraz spektrum klinicznego tej choroby.

Opis przypadku. Przedstawiono przypadek noworodka płci męskiej z obumieraniem podskórnej tkanki tłuszczowej noworodków, u któ- 
rego stwierdzono rzadko opisywane powikłania, jakimi są podskórne zwapnienia dystroficzne oraz zaniki podskórnej tkanki tłuszczowej.

Wnioski. Najistotniejsza z klinicznego punktu widzenia jest możliwość współistnienia obumierania podskórnej tkanki tłuszczowej noworodków z szeregiem zaburzeń metabolicznych. Miejscowe powikłania choroby występują rzadko. Obserwacja pacjenta jest niezbędna, aby określić następstwa estetyczne i funkcjonalne oraz możliwości leczenia ewentualnych powikłań tego schorzenia.

Key words: subcutaneous fat necrosis of the newborn, therapeutic hypothermia, dystrophic calcifications, subcutaneous atrophy.

Słowa kluczowe: obumieranie podskórnej tkanki tłuszczowej noworodków, hipotermia terapeutyczna, zwapnienia dystroficzne, zanik tkanki podskórnej.

\section{INTRODUCTION}

Subcutaneous fat necrosis of the newborn is a rare and self-limiting form of panniculitis which occurs mostly in full-term and post-term neonates during the first 6 weeks of life [1]. Accurate diagnosis is important mainly because of the possible coexistence of life-threatening metabolic disorders. Lesions within the subcutaneous fat tissue usually resolve without sequelae. Relatively rare complications include subcutaneous atrophy and dystrophic calcifications, fibrosis or scarring [2,3].

\section{OBJECTIVE}

To present the clinical spectrum of subcutaneous fat necrosis of the newborn based on the example of a patient diagnosed and treated at the University Clinical Centre in Gdańsk.

\section{CASE REPORT}

On the $10^{\text {th }}$ day of life a male neonate born from the first pregnancy (birth weight: $4000 \mathrm{~g}$ ) developed infiltrated erythematous lesions located on the skin of the chest, back and shoulders (fig. 1).

The newborn was delivered by caesarean section in the $41^{\text {st }}$ week of pregnancy because of imminent foetal asphyxia. At birth, the baby was in severe condition requiring resuscitation (Apgar score 1-1-1). He was transferred to a tertiary referral hospital because of persistent pulmonary hypertension secondary to meconium aspiration syndrome. To prevent hypoxic-ischaemic encephalopathy, therapeutic passive hypothermia was administered. During the first days of life, the newborn showed signs of multiple organ

\section{WPROWADZENIE}

Obumieranie podskórnej tkanki tłuszczowej noworodków jest rzadkim, samoograniczającym się zapaleniem tkanki podskórnej obserwowanym najczęściej u donoszonych lub urodzonych po czasie noworodków w pierwszych 6 tygodniach życia [1]. Rozpoznanie jest istotne głównie ze względu na możliwość współistnienia zagrażających życiu zaburzeń metabolicznych. Zmiany w obrębie podskórnej tkanki tłuszczowej ustępują zwykle bez śladu. Stosunkowo rzadkim powikłaniem są zaniki podskórnej tkanki tłuszczowej, podskórne zwapnienia dystroficzne, włóknienie lub bliznowacenie [2, 3].

\section{CEL PRACY}

Przedstawienie spektrum klinicznego obumierania podskórnej tkanki tłuszczowej noworodków na podstawie przypadku pacjenta diagnozowanego i leczonego w Uniwersyteckim Centrum Klinicznym w Gdańsku.

\section{OPIS PRZYPADKU}

U noworodka płci męskiej z ciąży pierwszej (masa urodzeniowa $4000 \mathrm{~g}$ ) w 10. dobie życia wystąpiły zmiany rumieniowo-naciekowe umiejscowione na skórze gładkiej klatki piersiowej, pleców oraz ramion (ryc. 1).

Poród odbył się w 41. tygodniu ciąży poprzez cięcie cesarskie ze względu na zagrażającą zamartwicę płodu. Noworodek urodzony w stanie ciężkim, po porodzie wymagał resuscytacji (Apgar 1-1-1). Następnie został przekazany do ośrodka o III $^{\circ}$ referencyjności z powodu przetrwałego nadciśnienia płucnego będącego powikłaniem zespołu aspiracji smółki. W celu 

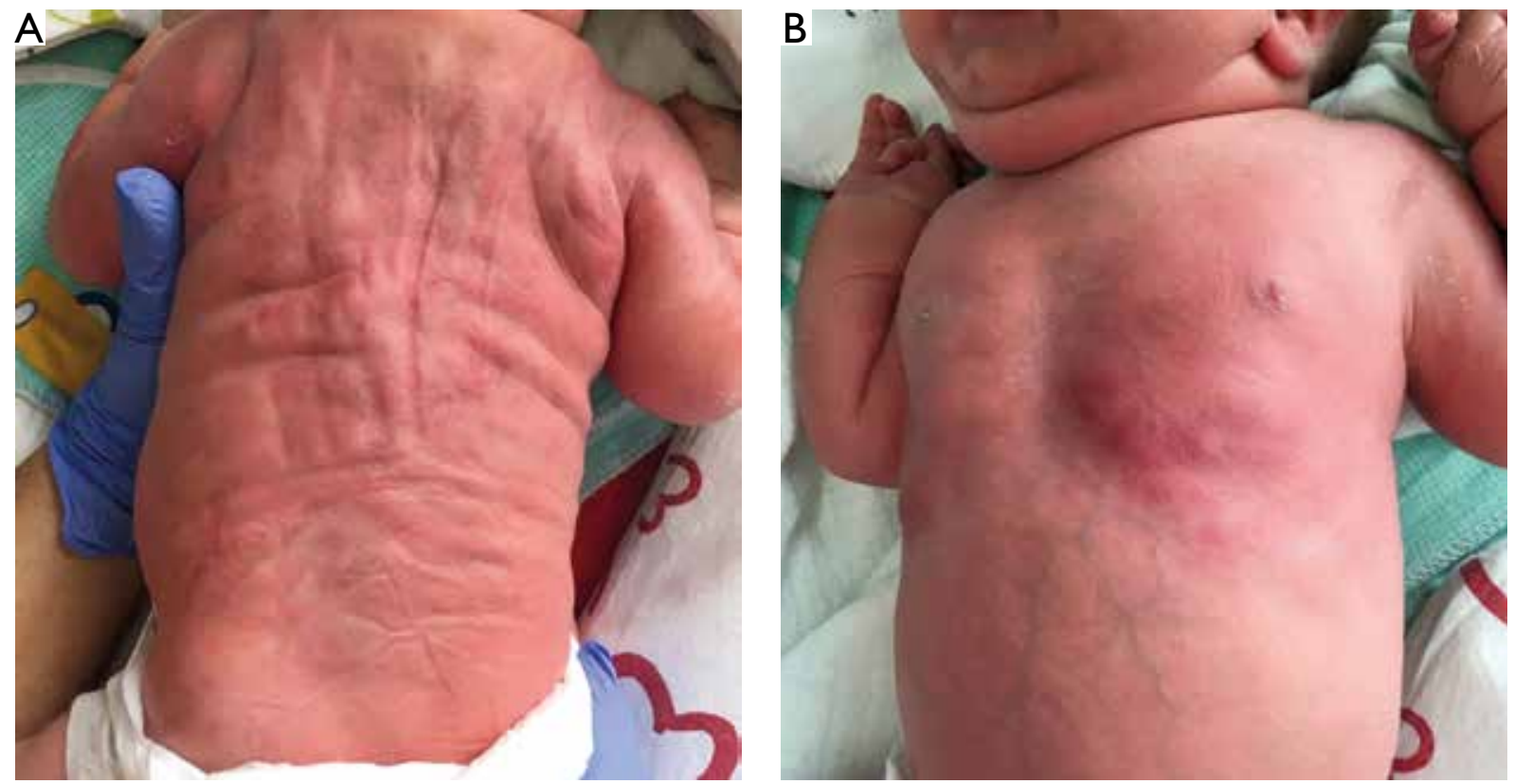

Figure I. Subcutaneous fat necrosis of the newborn. Clinical presentation at $10^{\text {th }}$ day of life: infiltrated erythematous lesions located on the chest, back and shoulders

Rycina I. Obumieranie podskórnej tkanki tłuszczowej noworodków. Obraz kliniczny w 10. dobie życia: zmiany rumieniowo-naciekowe umiejscowione na skórze klatki piersiowej, pleców oraz ramion

dysfunction syndrome including oliguria, oedema, increased creatinine level, elevated transaminase activity, hypoglycaemia, hypoalbuminaemia, hyponatraemia and blood coagulation disorders. After the newborn's condition was relatively stabilized, thrombocytopaenia and increasing levels of inflammatory markers were observed from the $6^{\text {th }}$ day of life. Since infection was suspected, a blood culture was ordered and empiric intravenous antibiotic therapy was initiated (vancomycin at a dose of $40 \mathrm{mg}$ every 12 hours, meropenem at a dose of $80 \mathrm{mg}$ every 12 hours). On the $10^{\text {th }}$ day of life, infiltrated erythematous lesions were observed on the boy's back, and on the skin of the chest and shoulders on subsequent days. Microscopic examination of a skin sample revealed small foci of fat tissue necrosis with sparse xanthogranulomatous reaction, granulation and fibrosis in the superficial layer of adipose tissue adjacent to the dermis (figs. 2 A, B). The findings were consistent with the clinical suspicion of subcutaneous fat necrosis of the newborn.

Over the course of the next several days of life, a progression of skin lesions was observed, accompanied by thrombocytopaenia and hypertriglyceridaemia. The skin lesions resolved almost completely after 5 weeks (fig. 3). A clinical improvement in laboratory findings was associated with concurrent hypercalcaemia (with total and ionized calcium levels of $4.8 \mathrm{mmol} / 1$ and $2.2 \mathrm{mmol} / 1$, respectively) and hypertriglyceridaemia (max. $613 \mathrm{mg} / \mathrm{dl}$ ). Despite intensive symptomatic treatment, the patient profilaktyki encefalopatii niedotlenieniowo-niedokrwiennej dziecko poddawano biernej hipotermii terapeutycznej. W pierwszych dobach życia stwierdzono objawy niewydolności wielonarządowej, tj. oligurię, obrzęki, zwiększone stężenie kreatyniny, podwyższoną aktywność transaminaz, hipoglikemię, hipoalbuminemię, hiponatremię i zaburzenia krzepnięcia. Po okresie względnej stabilizacji stanu ogólnego, od 6. doby życia obserwowano małopłytkowość i narastanie parametrów stanu zapalnego. Ze względu na podejrzenie infekcji zlecono posiew krwi i rozpoczęto empiryczną antybiotykoterapię ogólną (wankomycyna w dawce $40 \mathrm{mg}$ co 12 godzin, meropenem w dawce $80 \mathrm{mg}$ co 12 godzin). W 10. dobie życia pojawiły się zmiany rumieniowo-naciekowe na grzbiecie, a w kolejnych dobach na skórze klatki piersiowej oraz ramion. W obrazie mikroskopowym wycinka skóry obecne były drobne ogniska martwicy tkanki tłuszczowej ze skąpym odczynem ksantogranulomatycznym, ziarninowaniem i włóknieniem w obrębie powierzchownej warstwy tkanki tłuszczowej przylegającej do skóry właściwej (ryc. 2 A, B), co potwierdziło kliniczne podejrzenie obumierania podskórnej tkanki tłuszczowej noworodków.

W kolejnych kilkunastu dniach obserwowano progresję zmian skórnych z utrzymującą się małopłytkowością oraz hipertrójglicerydemią. Po 5 tygodniach zmiany skórne prawie całkowicie ustąpiły (ryc. 3). Jednocześnie z poprawą kliniczną w badaniach laboratoryjnych stwierdzono hiperkalcemię (ze stężeniem wapnia całkowitego sięgającym 4,8 mmol/1 oraz 

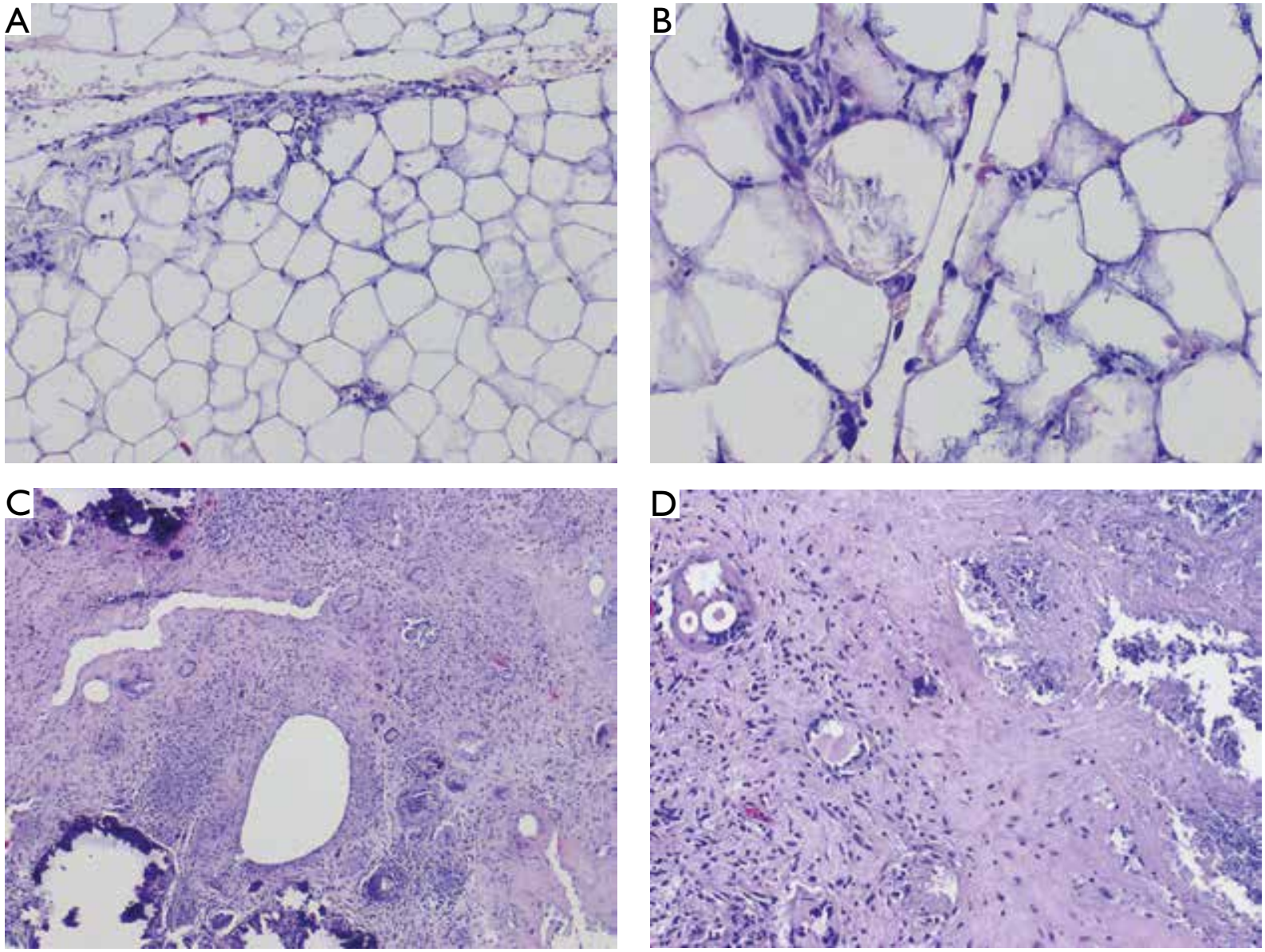

Figure 2. Subcutaneous fat necrosis of the newborn - histopathological presentation. A, B - Early stage of the disease with the predominance of necrobiotic and resorptive areas, and the presence of small paraseptal granulomas in adipose tissue lobules, accompanied by discreet crystalloids. C, D - Late phase with areas of sclerosis, disseminated granulomas (primarily multinucleated giant cells) and dystrophic calcifications

Rycina 2. Obumieranie podskórnej tkanki tłuszczowej noworodków - obraz histopatologiczny. A, B - Wczesna faza zmian, głównie o charakterze nekrobiotyczno-resorpcyjnym, z obecnościq drobnych ziarniniaków paraseptalnych w zrazikach tkanki tłuszczowej i dyskretnych krystaloidów. C, D - Zmiany późne tworzq̨ce obszary sklerotyzacji z rozproszonymi ziarniniakami (głównie komórki olbrzymie wielojqdrowe) i dystroficznym wapnieniem

developed bilateral nephrocalcinosis as a complication of hypercalcaemia. During a follow-up visit at 8 months old, asymptomatic, hard, subcutaneous nodules together with areas of atrophy were identified in the sites previously affected by subcutaneous fat necrosis (fig. 4). A microscopic examination of a biopsy sample taken from one of the nodules revealed the presence of dystrophic calcifications (figs. $2 \mathrm{C}, \mathrm{D}$ ). Despite a history of peripartum complications the child's psychomotor development seems to be normal.

\section{DISCUSSION}

Subcutaneous fat necrosis of the newborn (Cruise, 1875) is a rare and self-limiting form of panniculitis which occurs mostly in full-term and post-term neonates during the first 6 weeks of life $[1,2]$. The disease initially presents as oedematous lesions followed by wapnia zjonizowanego do 2,2 mmol/l) oraz hipertrójglicerydemię (do $613 \mathrm{mg} / \mathrm{dl}$ ). Mimo intensywnego leczenia u pacjenta rozwinęła się obustronna nefrokalcynoza jako powikłanie hiperkalcemii. W 8. miesiącu życia, podczas wizyty kontrolnej, w miejscach wcześniej objętych obumieraniem podskórnej tkanki tłuszczowej obecne były asymptomatyczne, spoiste guzki podskórne współistniejące z atrofią podskórnej tkanki tłuszczowej (ryc. 4). W obrazie mikroskopowym wycinka jednego z guzków stwierdzono zwapnienia dystroficzne (ryc. 2 C, D). Mimo przebytych powikłań okołoporodowych rozwój psychoruchowy dziecka wydaje się prawidłowy.

\section{OMÓWIENIE}

Obumieranie podskórnej tkanki tłuszczowej noworodków (Cruise, 1875) jest rzadkim, samoograniczającym się zapaleniem tkanki podskórnej, występującym 

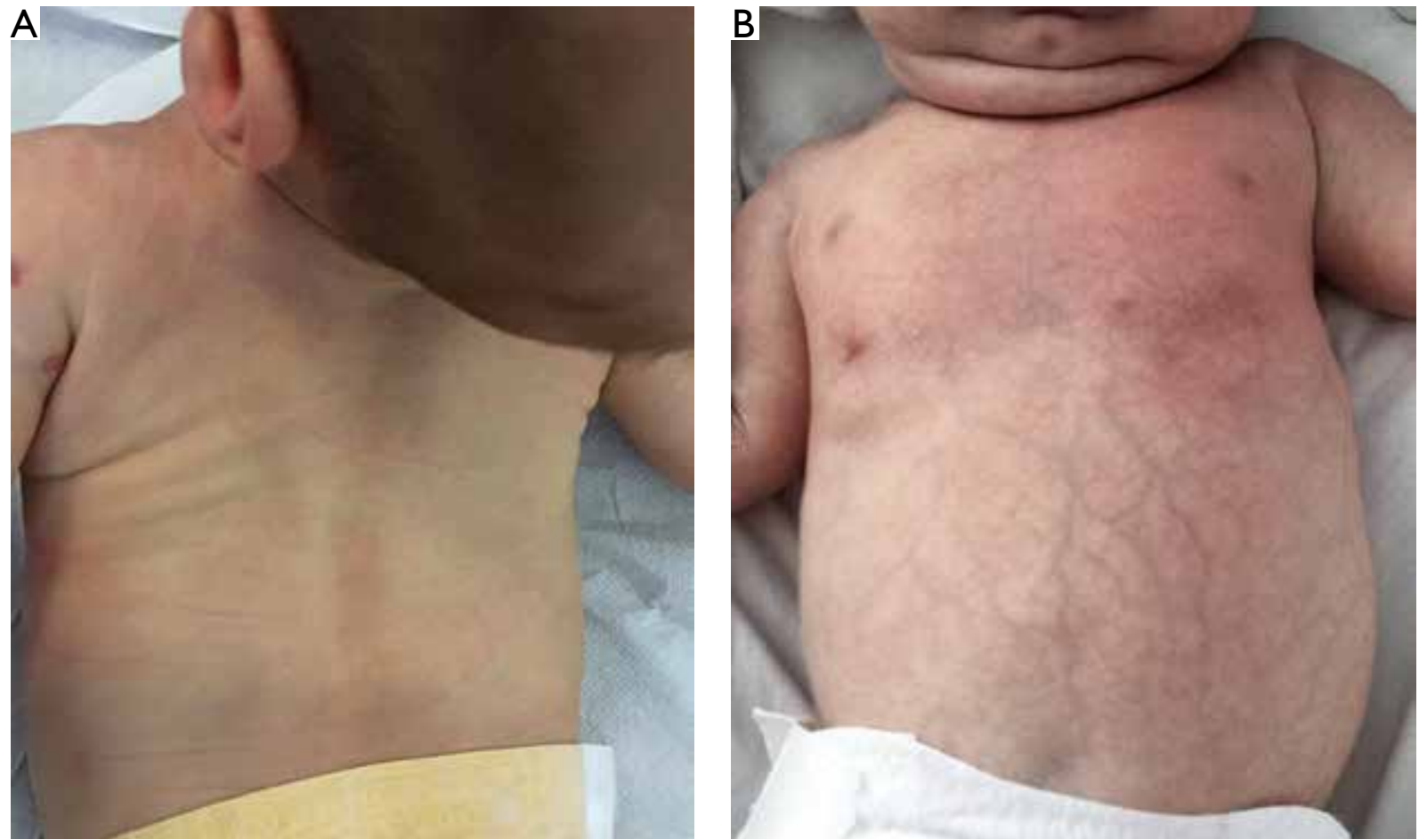

Figure 3. Clinical presentation after 5 weeks - almost complete resolution of the lesions

Rycina 3. Obraz kliniczny po 5 tygodniach - niemal całkowite ustapienie zmian chorobowych

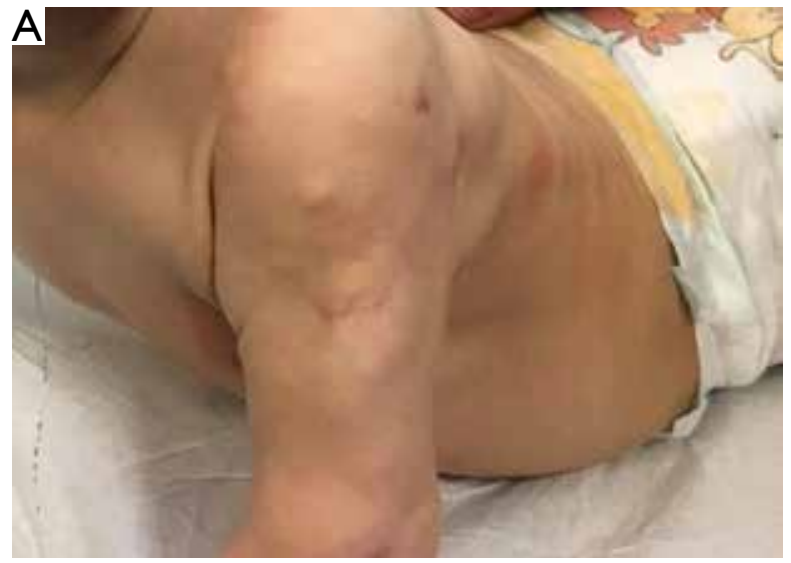

Figure 4. Clinical presentation after 8 months - asymptomatic, hard, subcutaneous nodules and areas of atrophy in the locations previously affected by subcutaneous fat necrosis

Rycina 4. Obraz kliniczny po 8 miesiq̨cach - w miejscach wcześniej objętych obumieraniem podskórnej tkanki tłuszczowej obecne asymptomatyczne, spoiste guzy podskórne oraz obszary zaniku tkanki podskórnej

plaques or nodules in the subcutaneous tissue. The overlying skin typically changes to a red or purple colour, however it may also remain unchanged. The lesions are usually located on the trunk, less commonly on the buttocks, arms and face. The aetiopathogenesis of the disease has not been clearly understood, however risk factors include, among others,

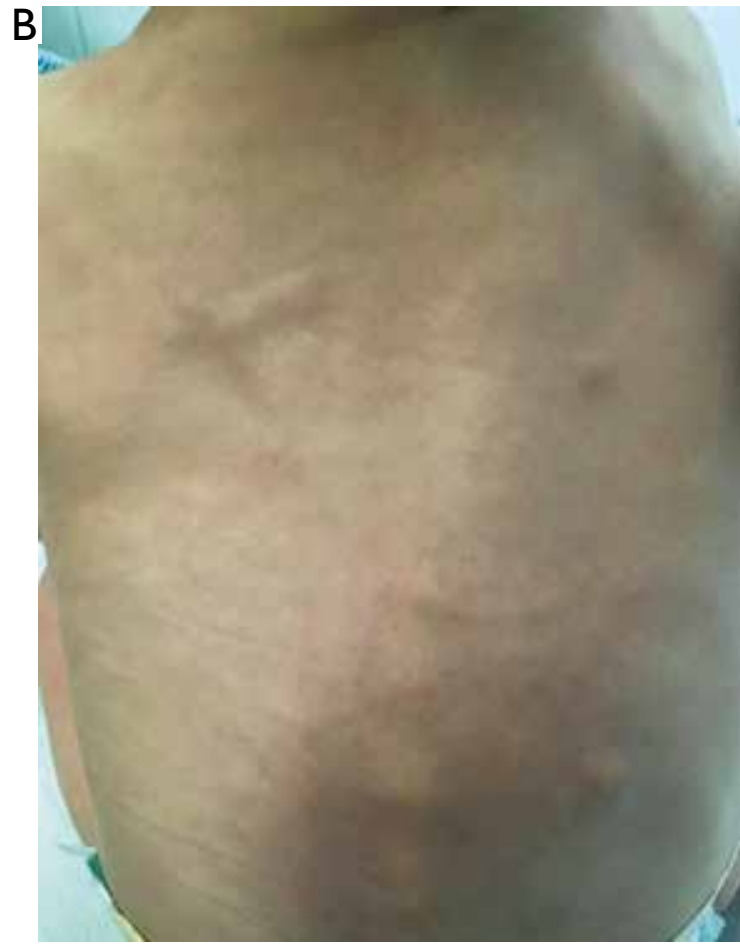

najczęściej u donoszonych lub urodzonych po czasie noworodków w pierwszych 6 tygodniach życia [1, 2]. Schorzenie charakteryzuje się występowaniem początkowo zmian obrzękowych, a następnie blaszek lub guzów w tkance podskórnej. Leżąca powyżej skóra przyjmuje typowo barwę czerwoną lub purpurową, lecz może być niezmieniona. Zmiany najczęściej umiej- 
perinatal hypoxia, use of therapeutic hypothermia, meconium aspiration syndrome, preeclampsia in the mother, gestational diabetes, exposure to tobacco smoke during pregnancy, Rh incompatibility and treatment with calcium channel blockers in the mother during pregnancy [2-4].

The diagnosis is established on the basis of features of lobular panniculitis seen in histopathological analysis (importantly, the biopsy specimen should comprise the skin together with subcutaneous tissue) or in material obtained by fine-needle aspiration biopsy.

Subcutaneous fat necrosis of the newborn should be differentiated primarily with neonatal scleroderma and cold panniculitis, and then with such conditions as erysipelas, angiomas and neurofibromas [2, 3, 5].

Since the disease has a self-limiting course, no treatment is necessary. However, sufficiently early diagnosis is important for detecting potential coexisting metabolic disorders, particularly hypercalcaemia which occurs in $25 \%$ of patients. The risk of this metabolic complication is higher in cases with extensive lesions and involvement of the subcutaneous tissue of the trunk $[6,7]$. Since the disease may lead to severe complications, calcium concentration monitoring during the initial 6 months of life is indicated in every neonate with a clinical suspicion of the disease. In addition to the calcium level, the concentration of glucose, platelet count and lipid profile should also be monitored [2-4].

Lesions within the subcutaneous fat tissue usually resolve without sequelae. However, the incidence of complications of subcutaneous fat necrosis of the newborn may be underestimated because longterm observations are scarce [3, 5-8]. In the study conducted by Mahé et al. [3], subcutaneous atrophy was observed in all 6 patients followed up for 9-27 months.

Subcutaneous dystrophic calcifications have been reported less commonly [5-8]. There are no studies describing the long-term nature of these lesions. Beuzeboc Gerard et al. have reported a single case of the disease complicated by the formation of massive calcifications involving the shoulders and back of a female patient who required surgical intervention for functional reasons [9].

In isolated cases, patients with subcutaneous fat necrosis of the newborn have been reported to develop complications including tissue softening, exudation and scarring $[2,3]$.

\section{CONCLUSIONS}

We report a case of a patient with subcutaneous fat necrosis of the newborn who was diagnosed and treated at the University Clinical Centre in Gdańsk. scowione są na tułowiu, rzadziej na pośladkach, ramionach oraz twarzy. Etiopatogeneza choroby nie została dotąd dokładnie poznana. Do czynników ryzyka należą m.in.: niedotlenienie okołoporodowe, stosowanie hipotermii terapeutycznej, zespół aspiracji smółki, stan przedrzucawkowy u matki, cukrzyca ciążowa, ekspozycja na dym tytoniowy w ciąży, konflikt serologiczny w układzie Rh, stosowanie przez kobietę w ciąży leków z grupy antagonistów kanałów wapniowych [2-4].

Potwierdzeniem rozpoznania są cechy zrazikowego zapalenia tkanki tłuszczowej obserwowane w badaniu histopatologicznym (istotne, aby wycinek zawierał skórę wraz z tkanką podskórną) lub materiale uzyskanym poprzez biopsję aspiracyjną cienkoigłową.

Obumieranie podskórnej tkanki tłuszczowej noworodków należy różnicować głównie z twardziną noworodków oraz zapaleniem tkanki podskórnej wywołanym zimnem, a następnie m.in. z różą, naczyniakami, nerwiakowłókniakami [2,3,5].

Ze względu na samoograniczający charakter choroba nie wymaga leczenia. Wczesne rozpoznanie jest ważne ze względu na możliwość wykrycia współistniejących zaburzeń metabolicznych, z których najistotniejsza jest hiperkalcemia, obserwowana u 25\% pacjentów. Ryzyko wystąpienia tego powikłania jest większe w przypadku rozległych zmian oraz zajęcia tkanki podskórnej tułowia $[6,7]$. Ze względu na możliwość wystąpienia poważnych powikłań wskazane jest monitorowanie stężenia wapnia w pierwszych 6 miesiącach życia u każdego noworodka z klinicznym podejrzeniem choroby. Poza tym należy kontrolować stężenie glukozy, liczbę płytek krwi oraz lipidogram [2-4].

Zmiany w obrębie podskórnej tkanki tłuszczowej ustępują zwykle bez śladu. Możliwe, że częstość występowania powikłań obumierania podskórnej tkanki tłuszczowej noworodków bywa niedoszacowana z powodu nielicznych obserwacji długoterminowych [3, 5-8]. W analizie przeprowadzonej przez Mahé i wsp. [3] zaniki podskórnej tkanki tłuszczowej stwierdzono u wszystkich 6 pacjentów obserwowanych przez 9-27 miesięcy.

Nieco rzadziej opisywano przypadki podskórnych zwapnień dystroficznych [5-8]. Nie ma badań dotyczących natury tych zmian w perspektywie wieloletniej. Beuzeboc Gerard i wsp. przedstawili jedyny przypadek powstania masywnych zwapnień obejmujących ramiona oraz grzbiet pacjentki, która wymagała interwencji chirurgicznej z przyczyn funkcjonalnych [9].

W pojedynczych przypadkach obumierania podskórnej tkanki tłuszczowej noworodków opisywano takie powikłania, jak rozmiękanie, sączenie oraz bliznowacenie $[2,3]$.

\section{WNIOSKI}

Prezentujemy przypadek pacjenta z obumieraniem podskórnej tkanki tłuszczowej noworodków, który był 
It cannot be ruled out that an increased use of therapeutic hypothermia will contribute to an elevated incidence of the disease. From the clinical point of view, the most important factor to consider is the possible coexistence of subcutaneous fat necrosis of the newborn with a range of metabolic disorders. Local complications of the disease are probably rare, however their incidence may be underestimated, given the scarcity of long-term studies.

\section{CONFLICT OF INTEREST}

The authors declare no conflict of interest. diagnozowany i leczony w Uniwersyteckim Centrum Klinicznym w Gdańsku. Nie można wykluczyć, że częstsze stosowanie terapeutycznej hipotermii przyczyni się do zwiększenia częstości występowania tej choroby. Najistotniejsza z klinicznego punktu widzenia jest możliwość współistnienia obumierania podskórnej tkanki tłuszczowej noworodków z szeregiem zaburzeń metabolicznych. Miejscowe powikłania choroby występują prawdopodobnie rzadko, choć ich częstość może być niedoszacowana ze względu na nieliczne badania długoterminowe.

\section{KONFLIKT INTERESÓW}

Autorzy deklarują brak konfliktu interesów.

\section{References}

\section{Piśmiennictwo}

1. Crus P.: Ein fall von sclerodermie sogenannt sclerodermis adulotorum bei saighing. Zeitichrify 1875, 5, 306.

2. Marszałek A., Maciejewska J., Bowszyc-Dmochowska M., Prokurat A.: Subcutaneous fat necrosis of the newborn - a case report and review of literature. Pol J Pathol 2010, 61, 240-244.

3. Mahé E., Girszyn N., Hadj-Rabia S., Bodemer C., Hamel-Teillac D., De Prost Y.: Subcutaneous fat necrosis of the newborn: a systematic evaluation of risk factors, clinical manifestations, complications and outcome of 16 children. Br J Dermatol 2007, 156, 709-715.

4. Rubin G., Spagnut G., Morandi F., Valerio E., Cutrone M.: Subcutaneous fat necrosis of the newborn. Clin Case Rep 2015, 3, 1017-1020.

5. Tran J.T., Sheth A.P.: Complications of subcutaneous fat necrosis of the newborn: a case report and review of the literature. Pediatr Dermatol 2003, 20, 257-261.

6. De Campos Luciano Gomes M.P., Porro A.M., da Silva Enokihara M.M.S., Floriano M.C.: Subcutaneous fat necrosis of the newborn: clinical manifestations in two cases. An Bras Dermatol 2013, 88, 154-157.

7. Burden A.D., Krafchik B.R.: Subcutaneous fat necrosis of the newborn: a review of 11 cases. Pediatr Dermatol 1999, 16, 384-387.

8. Maciejewska-Radomska A., Wilkowska A., Jagłowska J., Wierzba J., Roszkiewicz J.: Rzadki przypadek obumierania podskórnej tkanki tłuszczowej u noworodków. Przegl Dermatol 2011, 98, 317-321.

9. Beuzeboc Gérard M., Aillet S., Bertheuil N., Delliere V., Thienot S., Watier E.: Surgical management of subcutaneous fat necrosis of the newborn required due to a lack of improvement: a very rare case. Br J Dermatol 2014, 171, 183-185.

Received: 28.07.2017

Accepted: 13.09 .2017

Otrzymano: $28.07 .2017 \mathrm{r}$.

Zaakceptowano: $13.09 .2017 \mathrm{r}$. 